\title{
Work-Family Conflict: Coping Strategies to Optimise Healthy Living and Wellbeing Among Career Couples in Lagos Metropolis
}

\author{
Temitope Joshua Owolabi \\ Department of Sociology, University of Lagos \\ Kayode Agbolahan Ajibose \\ Human Capital Department, Fintrak Software Company Limited
}

\begin{abstract}
Work and Family are two central and independent sphere of life for dual career couples and an imbalance in one system may subsequently influence the other as well because today's emerging and diverse work area has reported significant increase in women, single parents and dual career couples as employees. As the cost of living is increasing at the alarming rate, the husband of the house that used to be "bread winner" makes himself a "bread partner" with the wife in order to cope with the economic hardship and financial obligation at the home front. Working couples not only look for their own career prospective but also attend to their family demands like house cleaning, catering for ageing ones, attending family parties, visiting recreational centres, attending religious programmes, nurturing of children and contribute to their future prospects as well. Work and family responsibilities along with long working hours in professional setup has resulted in conflict which in turn has affected the overall health and well-being of individuals. In dealing with multiple roles and work pressure and for enhancing well-being, working couples use coping strategies depending on their individual experiences and organisational policies. The paper utilised a mixed method; 10 respondents for the qualitative method to interview ten (10) respondents (five males, five females) as well as a quantitative study for 290 respondents. Findings reveal that effectiveness of coping strategies is a subject of unique experience and personal characteristics with some level of organisational support. This paper explores an approach towards the role of work-family conflict and coping mechanism in determining the wellbeing of working couples towards the actualisation of Goal 3 of SDGs by United Nations (i.e. Good Health and Wellbeing for People).
\end{abstract}

Keywords:Work-Family Conflict, Coping Strategies, Healthy Living, Wellbeing, Career Couples, Lagos Metropolis

DOI: $10.7176 /$ RHSS/9-8-08

Publication date: April $30^{\text {th }} 2019$

\section{INTRODUCTION}

Work life balance is a relevant issue in today's world of work, because evolving and various work areas have documented significant increase in the contribution of women, men and career couples who want to make ends meet in order to meet family obligations. These working couples are not only concerned with their own career potentials, but also interested in nurturing their wards in order to help build a reasonable life for them, as well as a better future prospect (Pleck, 1997). This is why work life balance is a pertinent issue in present time, as it has become imperative to understand the influence of change in work and family domain on wellbeing of employed parents because people perform several roles in life and shelving these responsibilities is not an option and thus consequences for individual are imminent. As corroborated in Roopa \& Neha (2015), work and family responsibilities along with long working hours in professional setup have resulted in conflict which in turn affected the overall well-being of individuals. This majorly can be traced to the fact that the Nigerian society has witnessed a shift in traditional gender roles to non- traditional gender roles due to women empowerment and increase in dual career couples with young children. With this, variations in family structure have resulted in corresponding change in work and family accountabilities for husbands and wives (Allen, Herst, Bruck and Sutton, 2000).

Conceptualising work-life balance, Ramya (2014) states that it includes proper prioritizing between work (career and ambition) and lifestyle (health, pleasure, leisure, family and spiritual development/meditation). It is the degree to which a person is engaged in and satisfied with, in equal measure, his or her work and non-work roles (Greenhaus \& Powell, 2003). Kalliath \& Brough (2008) offered a broader definition of work life balance; which is explained as an individual's perception that their work and non-work activities are compatible and promote growth in accordance with their current life's priorities.

However, the failure to achieve the above stated goals, will result into work-family conflict. Work-family conflict is a process where there is an obstruction between work activities with family activities. Netemeyer, Boles and McMurrian (1996) describe work-family conflict as a form of inter role conflict in which the general demands of, time devoted to, and strain created by the job interfere with performing family-related responsibilities and other personal demands. Often times, the imbalance created as a result of this results into unhealthy living and poor wellbeing among employees. Findings from researches have documented the link between work-family conflict 
and lower family function, poor physical and psychological health as well as lower work satisfaction (Hill, 2005), lower family satisfaction (Bedeian, Burke \& Moffett, 1989), distress (Dikkers, Geurts, Dulk, Peper, Taris \& Kompier, 2007), depression and alcohol abuse (Grzywacz \& Marks, 2000). Employees experiencing higher levels of stress caused by work-family conflict seem to be less satisfied with their jobs, less productive and less committed to the organisation (Frye \& Breaugh, 2004), hence, little or no optimised healthy living and poor wellbeing.

Malik et al. (2010) further shows that unbalanced work-family life caused by increased work demands leads to higher levels of stress. This has negative impacts not only on the wellbeing of workers but also on their families (Hochschild, 1997), as it increases anxiety of individuals at work and at home (Doby \& Caplan, 1995), and leads to lower quality relationships with family members (e.g. spouse or children) (Parasuraman \& Greenhaus, 2002). On the other hand, employees with lower levels of work-family conflict experience higher levels of job satisfaction (Hill, 2005). Also, those individuals who spend more time with their families enjoy a higher quality of life (Greenhaus et al., 2003), an optimised healthy living and quality wellbeing.

Having established the concept of work-family conflict and its dynamics from the point of view of its impact on healthy living and employees' wellbeing, the study further tries to explicate the various strategies employed by both employers and employees to deal and cope with these problems. Findings from Lazarus and Folkman (1988) found social support, transition from subject, self-control and plans of problem-solving as a coping strategy to deal with pressing conditions.

According to Lazarus and Folkman (1984), "coping refers to the constantly changing cognitive and behavioral efforts to manage specific external and internal demands". Coping is believed to be a function to reveal stresses and difficulties by distracting from stressful resources. Coping strategies are the ways an individual, group or organization use to minimize the effects of stress (Belal et al., 2009). Lazarus and Folkman (1984), distinguish between problem-focused and emotion-focused coping strategies. Problem-focused coping strategies are directly involved with the purpose of solving the problems in hand by either changing, altering or removing the circumstances which are perceived as threatening (Thoits, 1986). In prior studies it was revealed that people use problem-focused coping strategies when they identify situations as changeable (Lazarus, 1991). Emotion-focused coping strategies are used to handle feelings of distress, rather than the actual problem itself. Emotion-focused coping is related to regulate the undesirable negative emotional distress as a consequences of perceived stress through means of actions or thoughts (Thoits, 1986; Lazarus \& Folkman, 1984).

Religious coping strategies consisting of elements of emotion-focused coping strategies and problem-focused coping strategies also include social support as a strategy to cope with the pressures by including advice, assistance, subsidies, emotional support and justifying the perceptions of the individual and his actions. The same thing is experienced with religious coping strategies, which include more practice of prayers and religious worship that focus on emotion. A religious coping strategy is more important and effective with stressful events that an individual cannot control.

Problem-focused coping style is proved to be effective in dealing with adverse situation and people reported positive well-being. Couples reported higher level of conflict when used high avoidant coping mechanism and results in lower life satisfaction. Women employ a number of coping strategies to buffer the effect of work-family conflict (Ugwu, 2013). When direct action is possible, people found problem focused style promising and when direct action is not approachable, emotion focused coping is effective (Lazarus, 1999).

It is to this end that this study sets out to examine work-family conflict and the coping strategies employed to optimise healthy living and wellbeing among working couples in Lagos metropolis. Hence, the study seeks to answer the questions: what are the various types of stress faced by career couples in Lagos metropolis, what are the coping strategies employed to mitigate work-family conflict among career couples in Lagos metropolis? What are the organisational supports (if any) that management of various organisations have put in place to drive workfamily balance?

\section{METHODS}

The study adopted a cross-sectional research design, and using a purposive sampling technique to select the study population and study location. Mixed method was used (that is, qualitative and quantitative techniques) ten (10) respondents (five males and five females) were selected for the former while 290 respondents were selected for the latter. According to Ahonsi \& Soyombo (1996), a purposive sampling technique is where the sample is selected on the basis of the researcher's knowledge of the study population.

The study population are male and female respondents that work within Lagos metropolis. Lagos state is located in south western Nigeria, and within latitudes $6^{\circ} 23^{\prime} \mathrm{N}$ and $6^{\circ} 41^{\prime} \mathrm{N}$ and longitude $3^{\circ} 9^{\prime} \mathrm{E}$ and $3^{\circ} 28^{\prime} \mathrm{E}$ (Taofiki, 2015). It is made up 20 urban local government areas. Metropolitan Lagos has much higher population density than any other city in Nigeria with an average density of 2400 persons $/ \mathrm{km} 2$ and an annual population growth rate of $3.23 \%$ to $5 \%$ (Odeleye, 2011; Population Lagos, 2017).

The population of the Lagos urban agglomeration grew from 10.3 million in 1995 to about 10.9 million in 1996 and to 9 million by the 2006 census figure, and as at 2015, the city of Lagos had hit the 24.5 million population 
mark and thus among the ten most populous cities in the world (Taofiki, 2015). By 2050, Lagos' population is expected to double, which will make it the 3rd largest city in the world but with less infrastructure than any other large cities of the world (Population Lagos, 2017).

Large flocks of people still migrate to Lagos in the hope of getting white collar jobs here, due to which Lagos has swelled, gulped up surrounding cities, and even encroached, forebodingly, into bordering states. This is still going on and the Populations Reference Bureau predicts Lagos will double in size in the next 15 years. The World Economic Forum (WEF) says Lagos is the fastest-growing city in the world, with a growth of 85 people per hour. The population growth of Lagos is faster than that of London and New York put together, with the two cities growing at a rate of 9 and 10 people per hour. This however informed the basis for this study because of its urban nature and the need for survival among its residents.

Research ethics were strictly adhered to because the consents of participants were sought before the research commenced and they were not forced to do so. Also the principle of confidentiality was upheld as the researchers promised respondents of non-disclosure of their identities.

\section{RESULTS}

\section{Socio-demographic characteristics}

Males and females were equally represented in the study, as they both represent $50 \%$ each for both gender. Majority fall within the age bracket 26-35 years, and this represents $57.1 \%$ of the population followed by ages 3645 representing $36.7 \%$ while respondents within 18-25 years represent a smaller fraction of the population with $7.1 \%$. Majority of the population falling into 26-35 years by implication signify how career couples venture more into early marriage as a result of reduction in school leaving age. Based on the nature of the study, all participants are married, and $96.4 \%$ are living with their spouses, while $3.6 \%$ are not currently living with their spouses. The population with children shows that majority of the respondents have just 1 child representing $35.7 \%$, followed by 2 children with $25.0 \%$, then 3 children with $21.4 \%$. 3.6\% have 4 children, while $14.3 \%$ have no children.

Following this data, it was also discovered that more respondents work in the banking/insurance and financial services sector. This is represented by $46.4 \%$, followed by other sectors like food and beverages among others representing 10.8\%. Agriculture, Education and Telecommunication/ICT sectors are represented with $10.7 \%$ each. Apart from those who work with the private sector, $7.1 \%$ work with the Government while $3.6 \%$ work with the health sector (Hospitals, Health Management Office, etc).

Furthermore, majority of the respondents representing 42.9\% work between 40-44 hours a week, followed by $39.3 \%$ that work over 45 hours a week. However, $7.1 \%$ of the respondents work less than 24 hours a week, while 3.6\% represents respondents that work 25-29 hours a week, 30-34 hours a week and 35-39 hours a week.

With regards to the length of service with their organisations, just a few had worked for over 14 years with their organisations. This is represented by $3.6 \%$ of the entire population. But more people are represented haven worked for their organisation between 1-3 years, being represented by $66.6 \%$. Respondents who have worked between 10-13 years represent $11.1 \%$, while those who have worked between $4-6$ years represent $14.8 \%$ of the population.

\section{Availability of work-life balance at workplace}

This session identified various dimensions and availability of work-life balance among respondents, and it was discovered that for FLEXTIME system, majority stated it is not available but needed in their organisations, this is represented by $37.0 \%$. $29.6 \%$ stated that flexitime is not available and on the other hand, it is not needed in the organisation. $25.9 \%$ believe that the system is available in their organisation and it is used, while $7.5 \%$ believe that though available, it is not used.

The availability of COMPRESSED WORK WEEK shows that majority (44.4\%) of the participants would love to have this system in their organisation, but it is not available. This is followed $29.6 \%$ representing the population that believe that compressed work week is not available in their organisation and at the same time, it is not needed. $18.5 \%$ believe that the system is available in their organisation and used, while $7.5 \%$ was of the opinion that it is available but not used. In addition to this, TELECOMMUTING system is not too incorporated in the work structure of most organisations. This could be gotten from the study where $55.6 \%$ said that this system is not available, but it is highly needed to drive a balance between work and life. Although it is incorporated in some organisation as stated by $22.2 \%$ of the respondents, however, it is not being used. $14.8 \%$ believe it is not available and not needed, but $7.4 \%$ believe it is available but not used.

PART TIME WORK is another area the study tested in terms of availability of work-life balance, and majority representing $38.5 \%$ believe that this system is not available however, it is needed, while $30.8 \%$ believe it is not available and not needed. $23.1 \%$ believe this system is available and used, but $7.6 \%$ stated that the system is available but not used. With regards to ON-SITE CARE CENTRE, a significant proportion of the population representing $63.0 \%$ believe this policy is not available but actually needed by employees. $18.5 \%$ was of the opinion that it is available and used, while another $18.5 \%$ was of the opinion that the policy of on-site care centre is not available in their organisation and also not really needed. 
PAID MATRNITY/PATERNITY LEAVE was also examined and it was discovered that $40.7 \%$ believed that paid maternity/paternity leave is available and used in their organisation, $37.0 \%$ stated it is not available but needed in the organisation, $14.8 \%$ opined that paid maternity/paternity leave is available but not used, while $7.4 \%$ believed it is not available in their organisation but not needed.

\section{Work-family conflict}

Majority of the participants representing $28.6 \%$ strongly agree that the demands of their work interfere with their homes and family life, $21.4 \%$ disagree with this, while another $21.4 \%$ from the study population strongly agree. This is followed by $14.3 \%$ that agree that the demands of their work interfere with their homes and family life. $7.1 \%$ slightly disagree and another $7.1 \%$ strongly agree with the fact that the demands of their work interfere with their homes and family life.

Furthermore, majority disagree that the amount of time their jobs take up makes it difficult to fulfil their family responsibilities; this is represented by $28.6 \%$ of the study participants, this is followed by $17.9 \%$ that agree to this fact, and another $17.9 \%$ that slightly agree to this. $14.3 \%$ strongly agree of the time their jobs take from them, and $10.7 \%$ slightly disagree, while $7.1 \%$ strongly disagree with the fact that the amount of time their jobs take up makes it difficult to fulfil their family responsibilities. Also, majority of the participants representing $33.3 \%$ strongly agree that the things they want to do at home do not get done because of the demands their jobs put on them. Followed by $22.2 \%$ who agree with the fact that the home front suffers because of high demands from work. $18.5 \%$ of the participants were of the opinion that they strongly agree with the more demands at work compared to the home, and $11.1 \%$ slightly agree while another $11.1 \%$ strongly agree with this fact. A less significant proportion representing 3.6\% strongly disagree with the things they want to do at home do not get done because of their work demands. As a result of this, $33.3 \%$ of the population disagreed that their jobs produce strain that makes it difficult to fulfil their family duties. This is followed by $29.6 \%$ agree to this fact on how job strain produces failure to meet up with family duties. $18.5 \%$ slightly agree with this while $7.4 \%$ strongly agree, and another $7.4 \%$ strongly disagree to the fact that the strain from their jobs makes it difficult to fulfil their family duties.

Furthermore, majority $(40.7 \%)$ of the participants agreed that due to work related activities, they have had course to change plans for family activities. This change of plans have mitigated the time and strains their jobs would bring. This is followed by a little above a quintile $(22.2 \%)$ that disagree and said they have not had to make any changes. $18.5 \%$ strongly agree they have had the course to modify and changed their plans to suit and favour their family activities, while $14.8 \%$ slightly agree they have had to change their plans for their family activities. Data gathered shows that respondents have employed certain plans and measures to given room for their family activities. For example, adjusting leave period to when children are on vacation, school pick up for kids, delegating responsibilities to house maids, nannies or grandmothers, coming back home early from work, becoming selfemployed and shifting family activities to weekends among others. This is in consistency with a finding from an interview:

"...my husband is so supportive, we both fix our annual leaves the same time, and mostly when our children are on holiday. This gives us the opportunity to increase the time we spend with them. Because when they are on session, they spend a substantial amount of their time in school and lesson...' - Female, 36 years, Admin Executive

\section{Work and Family Satisfaction}

Majority of the participants strongly agree that in most ways, their family life is close to their ideal. This is represented by $29.6 \%$, while $22.2 \%$ disagree with this fact. $11.1 \%$ also slightly disagree with the fact that their family life is close to their ideal. $18.5 \%$ and $14.8 \%$ slightly agree and agree respectively about this assertion.

In the process of assessing the degree of their satisfaction with their family life, $29.6 \%$ forming the majority disagree they are satisfied with their family life. $25.9 \%$ slightly agree, $22.2 \%$ strongly agree, while $11.1 \%$ slightly disagree and another $11.1 \%$ agree that they are satisfied with their family life. In addition to this findings, $44.4 \%$ disagreed that if they could live their family life over again, they would change almost nothing. While $18.5 \%$ slightly agreed, $11.1 \%$ strongly disagree. $7.4 \%$ of the population further agreed to this assertion, although $7.3 \%$ also disagreed.

Generally, 37.0\% agree they are satisfied and happy with their current work, however, $18.5 \%$ disagree and stated they are not satisfied and happy with their work. $14.8 \%$ strongly agree they are happy, $7.4 \%$ strongly disagreed they are happy with their current work. Though $11.1 \%$ slightly agree, $11.1 \%$ feel indifferent that they are happy and satisfied with their current work. As a result of this feeling of happiness and satisfaction, majority $(22.2 \%)$ frequently think of leaving their current job, though same proportion $(22.2 \%)$ also disagreed they frequently think of leaving their current job. $18.5 \%$ also agree they do, $14.8 \%$ slightly agree they do, $11.1 \%$ strongly disagreed they frequently think of leaving their jobs. Though $7.4 \%$ slightly disagree they frequently think so, $3.5 \%$ feel indifferent about this. 
fact that they have not been able to concentrate on what they do while at work due to stress, this is followed by $18.5 \%$ who slightly agree, $14.8 \%$ strongly agree, while $7.4 \%$ strongly disagreed. Also, $7.4 \%$ agree they have not been able to concentrate, while $7.1 \%$ slightly disagree with this assertion. In furtherance of this, $40.7 \%$ disagreed that they have recently lost much sleep over worry about work related problems, but $18.5 \%$ strongly agree while another $18.5 \%$ agree of the loss of sleep over worry about work problems. $14.8 \%$ strongly disagreed with this assertion.

Furthermore, $29.5 \%$ disagreed they constantly feel they are under strain while $18.5 \%$ strongly agree they are constantly under strain. $14.8 \%$ slightly disagreed, while another $14.8 \%$ also strongly disagreed they constantly feel under strain. However, $11.1 \%$ agree, while another $11.1 \%$ slightly agree that they constantly feel under strain.

Assessing the confidence level of participants, majority disagree with the fact that they have been losing confidence in themselves. While $29.6 \%$ strongly disagree, $11.1 \%$ also slightly disagree. $11.1 \%$ of the respondents also tilts towards agreeing they are losing confidence in themselves. $10.2 \%$ slightly agree, $3.6 \%$ strongly agree they are losing confidence in themselves.

$33.3 \%$ being the majority strongly agree they have been feeling reasonably happy all things considered, while $18.5 \%$ disagree with this. This is followed by $14.8 \%$ that slightly agree they have been feeling reasonably happy, $11.1 \%$ also strongly agree they have been feeling reasonable happy, while another set of $11.1 \%$ slightly disagree they have been felling reasonably happy.

Table 1.1. Correlation for work-family conflict and family satisfaction

\begin{tabular}{|l|l|l|}
\hline & Work-Family Conflict & Family satisfaction \\
\hline Work-Family Conflict Correlation & 1 & $0.44^{* *}$ \\
Significant (2-tailed test) & & .003 \\
& 290 & 290 \\
\hline Family satisfaction & $-0.44^{* *}$ & 1 \\
Significant (2-tailed test) & .003 & 290 \\
\hline
\end{tabular}

The table above proposed that work-family conflict will be negatively correlated with family satisfaction. The relationship between work-family conflict (measured by work-family conflict scale) and family satisfaction (measured by family satisfaction scale) was examined using Pearson's product-moment correlation coefficient. There was a statistically significant medium negative correlation between the two variables, $r=-0.44, n=290, p$ $<0.01$, which indicates that the more work-family conflict is experienced by individuals the less satisfied they are with their family lives.

“... I feel so useless because I hardly find time for my family. The weekend I need to stay close to them, I go for lectures for my professional exams. Now tell me, what do I do? Because my husband's salary is not sufficient to cater for the home, he is a civil servant...'- Female, 32 years, Marketing Executive Table 1.2. Work-Family Conflict and Work Satisfaction

\begin{tabular}{|l|l|l|}
\hline & work-family conflict & work satisfaction \\
\hline work-family conflict Correlation & 1 & $-.28^{* *}$ \\
Significant (2-tailed test) & & .001 \\
& 290 & 290 \\
\hline work satisfaction & $-.28^{* *}$ & 1 \\
Significant (2-tailed test) & .001 & \\
& 290 & 290 \\
\hline
\end{tabular}

The table above shows that work-family conflict will be negatively correlated with work satisfaction. The relationship between work-family conflict (measured by work-family conflict scale) and work satisfaction (measured by work satisfaction scale) was examined using Pearson's product-moment correlation coefficient. There was a statistically significant but small negative correlation between the two variables, $r=-.28, n=290, p$ $<0.01$, which indicates that the more work-family conflict is experienced by individuals the less satisfied they are with their work. In line with this, a response from the interview reveals this findings:

"I do the work of about three people in my office, and this has taken away my time from my family. I work late most of the time, and this has led to me being estranged from my family. I am not really satisfied with this job because my organisation is just exploiting me and they don 't want to hire someone to assist me ". - Male, 35 years, 
Tax Personnel

Table 1.3. Work-Family Conflict and Psychological Distress

\begin{tabular}{|l|l|l|}
\hline $\begin{array}{l}\text { work-family conflict Pearson } \\
\text { Correlation }\end{array}$ & work-family conflict & psychological distress \\
Significant (2-tailed test) & 290 & $\begin{array}{l}. * * \\
.001 \\
290\end{array}$ \\
\hline $\begin{array}{l}\text { psychological distress Pearson } \\
\text { Correlation }\end{array}$ & $.40^{* *}$ & 1 \\
Significant (2-tailed test) & .001 & 290 \\
\hline
\end{tabular}

It was discovered that work-family conflict will be positively correlated with psychological distress. The relationship between work-family conflict (measured by work-family conflict scale) and psychological distress (measured by psychological health scale) was examined using Pearson's product-moment correlation coefficient. There was a statistically significant and medium positive correlation between the two variables, $r=.40, n=290$, $\mathrm{p}<0.01$, which indicates that the more work-family conflict is experienced by individuals the more psychological distress will be observed. This was in consistency with a finding from the qualitative study where a respondent said:

“... I feel so disintegrated with my family because of the little or no time I have for them due to my work demands. I work on the island, I leave home every day at 5 am and return nothing less than 9pm when my kids would have been asleep. It grieves me a lot and sometimes, it affects my job performance',- Female, 28 years, Health Consultant.

\section{DISCUSSION OF FINDINGS}

Work-family conflict was the first variable defining individuals' Work-Life Balance. Work and family literature indicates that work-family conflict occurs when work activities interfere with family activities. Netemeyer et al. (1996) described work family conflict as "a form of inter role conflict in which the general demands of, time devoted to, and strain created by the job interfere with performing family related responsibilities". The present study proposed that work-family conflict will be negatively related to family satisfaction and work satisfaction, and positively related to psychological distress.

It was hypothesized that work-family conflict will be negatively related to family satisfaction. This hypothesis was supported, and the correlation between the two variables in the current study was $r=-0.44$. These results suggest that the more work-family conflict is experienced by individuals the less satisfied they are with their family lives. This happens because participation in one domain makes it more difficult to participate in a second domain (Greenhaus \& Beutell, 1985); therefore, higher work demands may limit or prevent individuals from spending quality time with their families, which can lead to lower satisfaction with family life. This proves the argument that any work-related activities that interfere with family activities create conflict between work and family domains (Netemeyer et al., 1996). This conflict results in lower levels of satisfaction with family life amongst participants.

Findings from this study are consistent with previous research which reported negative correlations between work-family conflict and family satisfaction. Clark (2000) argued that work and family domains are the most important elements of everyone's life. Any competing demands of work and family life will cause conflict and negatively affect the wellbeing of workers (Frone, 2000; Clark, 2000). Several researchers (e.g. Frone, 2003; Parasuraman \& Greenhaus, 2002; Allen et al., 2000; and Netemeyer et al., 1996) conducted studies on relationships between work family conflict and family satisfaction, and found negative correlations between those two variables. These findings implied that employees experiencing higher levels of work-family conflict seemed to be less satisfied with their family lives. This was supported in this study.

This study proposed that work-family conflict will be negatively related to work satisfaction. This hypothesis was supported, and the correlation between the two variables was $r=-.28$. These findings indicate that the more work-family conflict is experienced by individuals the less satisfied they are with their work. This suggests that work-related duties, amount of time spent at work, and strain produced by work demands and pressure had negative effects on respondents' degree of contentment with the kind of work there were doing in their jobs, overall satisfaction with their work, and commitment to their employers. The findings from the current study prove the argument that work-related activities competing with family activities create time-based conflict (Yang, 2005), and pressures and demands of work role conflicting with the demands of family role create strain-based conflict (Edwards \& Rothbard, 2000). Results from the current study are consistent with past research conducted by Hill (2005), Allen et al. (2000) and Netemeyer et al. (1996) which reported negative relationships between work-family 
conflict and work satisfaction. In addition, Frye and Breaugh (2004) found that employees experiencing higher levels of work-family conflict seem to be less satisfied with their jobs, which leads to lower levels of commitment towards their organisation. This was supported by the results of this study. This study proposed that work-family conflict will be positively correlated with psychological distress. This hypothesis was supported, and the correlation between the two variables was $r=.40$. This result indicates that the more work family conflict is experienced by individuals the more psychological distress will be observed. These findings suggest that participants who experienced higher levels of work-family conflict caused by higher degrees of work pressure and demands, and longer time spent in employment, reported higher degrees of distress, concentration problems, sleeping problems, higher levels of unhappiness, strain, and lack of confidence.

\section{CONCLUSION AND POLICY IMPLICATION}

The study identified the existence of negative effects of poor work-life balance due to high levels of work-family conflict on family and job satisfaction as well as on the psychological health and wellbeing of career couples in Lagos metropolis. It was found that demands and pressure from work and family domains have an adverse impact on family satisfaction. In addition, higher levels of work demands and longer time spent in employment led to lower levels of quality time spent with families and lower family satisfaction. Work-family conflict resulted in lower satisfaction with work and commitment towards employers, and higher degrees of distress, concentration problems, sleeping problems, unhappiness, and lack of confidence; hence a resultant factor of unhealthy living a poor wellbeing.

This research showed that the main causes of work-family conflicts were excessive working hours and a lack of work schedule flexibility. The research also showed that apart from an increasing female workforce and twoincome households, the labour force is ageing.

This could lead to increased demands for more flexible working arrangements for employees with eldercare and childcare responsibilities. It was recognised that employers can improve work-life balance by implementing family-friendly initiatives such as flexi-time, compressed working week, time off in lieu, childcare support and eldercare support. Findings from the current study are important to both employees and employers in terms of a deeper understanding of work-life balance and its effects on people's wellbeing and healthy living, which consequently affects organisations' productivity and performance.

\section{REFERENCES}

Ahonsi Babatunde and Soyombo Omololu (1996). Social Research Methods and Applications. Ibadan, Oyo State. Caltop Publications Nigeria Limited

Allen, T. D., Herst, D. E. L., Bruck, C. S. \& Sutton, M. (2000) 'Consequences associated with work-family conflict: A review and agenda for future research'. Journal of Occupational Health Psychology, 5 (2): 278-308

Bedeian, A.G., Burke, B.G. \& Moffett, R.G. (1989) 'Outcomes of work-family conflict among married male and female professionals'. Journal of Management, 14 (3): 475-491.

Belal B. Hassan Y. Rusnah M., (2009). Religiosity and work stress coping behavior of Muslim employees, Education, Business and Society: Contemporary Middle. Eastern Issues, 2(2), 123-137

Clark, S. C. (2000) 'Work/family border theory: A new theory of work/family balance'. Human Relations, 53 (6): 747-770.

Dikkers, J.S.E., Geurts, S.A.E., Dulk, L.D., Peper, B., Taris, T.W. \& Kompier, M. (2007) 'Dimensions of workhome culture and their relations with the use of work-home arrangements and work-home interaction'. Work and Stress 21: 155- 72.

Doby, V.J. \& Caplan, R.D. (1995) 'Organisational stress as threat to reputation: Effects on anxiety at work and at home’. Academy of Management Journal, 38(4), 1105-1123.

Edwards, J. R. \& Rothbard, N. P. (2000) 'Mechanisms linking work and family: Clarifying the relationship between work and family constructs'. Academy of Management Review, 25 (1): 178199.

Frone, M. R. (2000) 'Work-family conflict and employee psychiatric disorders: The national comorbidity survey'. Journal of Applied Psychology, 85(6): 888- 895.

Frone, M. R. (2003) 'Work-family balance'. In: Quick, J.C. \& Tetrick, L.E. (eds). Handbook of occupational health psychology. Washington: American Psychological Association, 143-162.

Frye, N. \& Breaugh, J. (2004) 'Family-friendly policies, supervisor support, work-family conflict, family-work conflict, and satisfaction: A test of conceptual model'. Journal of Business and Psychology, 19 (2): 197-206.

Greenhaus, J. H. \& Beutell, N. J. (1985) 'Sources of conflict between work and family roles'. Academy of Management Review, 10 (1): 76-88.

Greenhaus, J. H., Collins, K. M. \& Shaw, J. D. (2003) 'The relation between work-family balance and quality of life'. Journal of Vocational Behaviour, 63 (3): 510-531.

Greenhaus, J. H., Collins, K. M. \& Shaw, J. D. (2003) 'The relation between work-family balance and quality of 
life'. Journal of Vocational Behaviour, 63 (3): 510-531.

Greenhaus, J.H., \& Powell, G.N. (2003), When Work and Family Collide: Deciding Between Competing Role Demands, Organizational Behaviour and Human Decision Processes, 90, 291-303.

Grzywacz, J.G. \& Marks, N.F. (2000) 'Reconceptualising the work-family interface: an ecological perspective on the correlates of positive and negative spillover between work and family'. Journal of Occupational Health Psychology, 5(1):111-126

Hill, E. (2005) 'Work-family Facilitation and Conflict: working fathers and mothers work-family stressors and support'. Journal of Family Issues, 26: 793- 819.

Hochschild, A. R. (1997) The time bind: When work becomes home and home becomes work. New York: Henry Holt and Company.

Kalliath, T., \& Brough, P. (2008), Work-Life Balance: A Review of the Meaning of the Balance Construct, Journal of Management and Organization, 14, 323-327.

Lazarus, R. folkman, S. (1988). Coping as Mediator of emotion. Journal of personality and social psychology, vol. 54, No. 3, pp 466-475

Lazarus, R.S. (1991). Emotion and adaptation. New York: Oxford University Press.

Lazarus, R.S. (1999). Stress and Emotion: A New Synthesis. Springer, New York.

Malgorzata, K. (2013) 'The Impact of Worl-Life Balance on the Wellbeing of Employees in the Private Sector in Ireland'. School of Business, National College of Ireland.

Malik, F., McKie. L., Beattie. R. \& Hogg, G. (2010) 'A Toolkit to Support Human Resource Practice'. Personnel Review, 39 (3): 287-307.

Netemeyer, R.G., Boles, J.S. \& McMurrian, R. (1996) 'Development and validation of work - family conflict and family - work conflict scales'. Journal of Applied Psychology, 81(4): 400410

Odeleye, J. A. (2011). Road traffic congestion management and parking infrastructural planning in metropolitan Lagos: The linkage. World Transport Policy \& Practice, 17, 27-36.

Parasuraman, S. \& Greenhaus, J. H. (2002) 'Toward reducing some critical gaps in work-family research'. Human Resource Management Review, 12: 299-312.

Pleck, J. (1997). Paternal involvement: Levels, sources, and consequences. In M. E. Lamb (Ed.), The role of the father in child development (pp. 66-103), third edition. New York: John Wiley \& Sons

Population of Lagos (2017). Population of Lagos. http://populationof2017.com/population-of lagos-2017.html. Assessed on $10^{\text {th }}$ December, 2018

Ramya, R. (2014). Work Life Balance Strategies of Women. International Journal of Research and Development - A Management Review; 2319-5479

Roopa, M \& Neha, S. (2015) Work-Family Conflict: Coping Strategies to Optimize Wellbeing in Working Couples. International Research Journal of Interdisciplinary \& Multidisciplinary Studies. Volume-I, Issue-IX, pp 1824

Taofiki Salau (2015). Public transportation in metropolitan Lagos, Nigeria: analysis of public transport users' socioeconomic characteristics. Urban, Planning and Transport Research. Vol. 3, no. 1, 132-139

Thoits, P.A. (1986). Social Support as coping assistance. Journal of Consulting and clinical Psychology, 54, 416423

Ugwu, L., (2013). Employed „"Sandwich Generation Women: Coping with Work/Family Conflict. European. Journal of Social Sciences, 15 (3), 396-410

Yang, N. (2005) 'Individualism-collectivism and work-family interface: A SinoUS comparison'. In: Poelmans, S.A.Y. (eds). Work and family: An international research perspective. London: Lawrence Erlbaum, 287-319. 